\title{
A New Selective Medium for Isolation of Clavibacter michiganensis subsp. michiganensis from Tomato Plants and Seed
}

\author{
Radwan M. Ftayeh, Andreas von Tiedemann, and Klaus W. E. Rudolph
}

Division of Plant Pathology and Crop Protection, Department of Crop Sciences, University of Göttingen, Germany. Accepted for publication 22 June 2011.

\begin{abstract}
Ftayeh, R. M., von Tiedemann, A., and Rudolph, K. W. E. 2011. A new selective medium for isolation of Clavibacter michiganensis subsp. michiganensis from tomato plants and seed. Phytopathology 101:13551364.

A new selective and highly sensitive medium was developed for isolation of Clavibacter michiganensis subsp. michiganensis $(\mathrm{Cmm})$, the causal agent of bacterial canker of tomato, from seed and latently infected plants. The new medium (BCT) proved to be superior to all published semiselective media for $\mathrm{Cmm}$ and is denoted as selective medium because of (i) its mean plating efficiency, amounting to $\leq 89 \%$ within 7 days for all $30 \mathrm{Cmm}$ strains from different sources tested; (ii) the high selectivity,

tent of 98 to $100 \%$; and (iii) the remarkable detection sensitivity. Thus, $8 \mathrm{CFU}$ of $\mathrm{Cmm}$ in field plant homogenates containing 12,750 CFU of accompanying saprophytes were detected on BCT. Under these extreme conditions, all of the published semiselective media (D2, KBT, D2ANX, SCM, mSCM, CMM1, mCNS, and EPPO) gave false-negative results. Either some media were rather toxic and $\mathrm{Cmm}$ growth was also inhibited or the other, less toxic media allowed growth of high numbers of saprophytes, so that $\mathrm{Cmm}$ growth was suppressed. Exclusively, BCT also supported growth of the closely related $C$. michiganensis subsp. insidiosus, nebraskensis, and tessellarius. The new medium is recommended for $\mathrm{Cmm}$ detection in tomato seed, and in symptomless tomato plantlets, to improve disease control of bacterial canker of tomato.
\end{abstract} because accompanying bacterial species occurring on tomato plants and seed or bacteria obtained from culture collections were inhibited to an ex-
Additional keywords: Solanum lycopersicum.
Clavibacter michiganensis subsp. michiganensis (Cmm) (Smith) Davis et al., the causal organism of bacterial canker of tomato (Solanum lycopersicum), has been classified as an $\mathrm{A}_{2}$ quarantine organism by the European Plant Protection Organization (EPPO) (27). Bacterial canker is a serious emerging disease of tomato worldwide wherever tomato plants are grown, and new outbreaks of the disease have been reported in several countries recently $(4,14,15)$

Infected or contaminated seed and transplants are responsible for disease transmission into new areas $(5,30,32)$, whereas transmission by soil appears to be of minor importance $(12,30)$. As few as 0.01 to $0.05 \%$ contaminated seed or transplants can cause an epidemic in suitable conditions (5). Therefore, indexing of tomato seed lots for $\mathrm{Cmm}$ is the key for disease control (3). However, some of the recent outbreaks occurred although infected plants were raised from tomato seed and transplants that had been certified as pathogen free when using some of the available semiselective media. The most often used detection assay for $\mathrm{Cmm}$ is based on dilution plating on semiselective media. Our study, started in mid-2006, revealed that the main weakness regarding the EPPO (27) and International Seed Health Initiative (ISHI) (22) protocols most likely was due to the recommendation of semiselective media that failed to detect low numbers of $\mathrm{Cmm}$ in infected tomato plants and seed, so that false-negative results were obtained in our experiments even when the plant and seed extracts had been spiked with $\mathrm{Cmm}$. Therefore, the aim of the present work was to develop a new selective and highly sensitive

Corresponding author: R. M. Ftayeh; E-mail address: rftayeh@gwdg.de

* The $\boldsymbol{e}$-Xtra logo stands for "electronic extra" and indicates that Figures 5, 6, and 7 appear in color online.

doi:10.1094/PHYTO-02-11-0045

(c) 2011 The American Phytopathological Society medium for routine seed testing and for a reliable isolation and detection of $\mathrm{Cmm}$ in infested seed and symptomless plants.

The strategy was, first, to develop an optimum basal medium for Cmm, followed by screening a large group of various antibiotics and inhibitors, and, finally, testing selected antibiotics and inhibitors in manifold combinations in order to develop a new medium that supports growth of various $\mathrm{Cmm}$ strains from different origins but suppresses a wide range of nontarget bacterial species and strains, such as other phytopathogenic bacterial species affecting tomato plants, and numerous epiphytic or saprophytic bacterial strains occurring on tomato plants and seed.

The finally developed new selective medium BCT (bacterial canker of tomato) also showed a remarkable specificity for other subspecies of $C$. michiganensis. The underlying mechanisms could not be explained completely. However, a further elucidation of the biochemical interactions involved may open a new avenue for better understanding the host-parasite relationship of these pathogens and their control.

\section{MATERIALS AND METHODS}

Bacterial strains and growth conditions. In all, 72 bacterial strains and species (Table 1) were used, including $30 \mathrm{Cmm}$ strains from different origins and 42 "accompanying" bacterial strains which may occur on tomato plants and seed. These epiphytic or saproyhytic strains and the phytopathogenic strains were isolated from tomato plants and seed or obtained from bacterial culture collections. Several saprophytic bacterial strains were antagonists of $\mathrm{Cmm}$ in vitro and taxonomically characterized by their whole cell fatty acid methyl esters (Table 2 ).

Working bacterial strains were cultured and stored on nutrient glucose yeast extract (NGY) medium at $4^{\circ} \mathrm{C}$ while stock cultures were maintained in $20 \%$ glycerol at $-80^{\circ} \mathrm{C}$. The NGY medium (14) contained $0.8 \%$ nutrient broth (Roth, Karlsruhe, Germany), $1 \%$ glucose, and $0.3 \%$ yeast extract (Roth); the $\mathrm{pH}$ value was 
adjusted to 7.2 with $\mathrm{HCl} / \mathrm{NaOH}$. Pseudomonads were also cultivated on King's medium B (KB) (25). For long-term preservation, strains were lyophilized and deposited in the Göttingen Collection (Sammlung) of Phytopathogenic Bacteria (GSPB).

Standardized bacterial suspensions were prepared from 24-hold NGY cultures in $0.01 \mathrm{M} \mathrm{MgSO}_{4}$. The bacterial concentrations were photometrically adjusted to $\approx 10^{8} \mathrm{CFU} / \mathrm{ml}$ (i.e., an optical density of 0.06 at $660 \mathrm{~nm}$ ), followed by 10 -fold serial dilutions down to the proper concentration. After surface plating onto test media, the agar plates were incubated at $26^{\circ} \mathrm{C}$ for 48 to $72 \mathrm{~h}$ in case of the NGY medium or longer in case of semiselective media or NGY supplemented with rifampicin and streptomycin.
Development of the basal medium for Cmm. Nine semiselective media without addition of antibiotics or other inhibitors were tested for growth of $\mathrm{Cmm}$ in comparison with growth on the NGY medium. The nine media were D2 (23); KBT (10); mCNS, which was prepared as suggested by Gitaitis et al. (17), based on CNS (18) and modified by omission of lithium chloride and Bravo 6F; D2ANX (6); SCM (11); mSCM (31); CMM1 (1,24); EPPO, the medium for $C m m$ recommended by the EPPO (27); and MTNA (20), which was developed for $C$. michiganensis subsp. sepedonicus. For evaluating the best-suited basal medium, three Cmm strains (GSPB 390, GSPB 2973, and Ei-2) differing in colony morphology and growth rate on NGY were selected.

TABLE 1. Origin of bacterial species and strains used to evaluate semiselective media

\begin{tabular}{|c|c|c|c|c|c|}
\hline Bacterial species & $\begin{array}{c}\text { GSPB } \\
\text { number }^{\mathrm{a}}\end{array}$ & $\begin{array}{l}\text { Designation or number } \\
\text { in other collections }{ }^{b}\end{array}$ & Origin $^{c}$ & $\begin{array}{c}\text { Year } \\
\text { of isolation }\end{array}$ & Isolated by ${ }^{\mathrm{d}}$ \\
\hline Clavibacter michiganensis subsp. michiganensis & 3199 & Amb-1 & Germany, R & 2006 & R. Ftayeh \\
\hline C. michiganensis subsp. michiganensis & 3200 & Ei-1 & Germany, NR & 2007 & R. Ftayeh \\
\hline C. michiganensis subsp. michiganensis & $\ldots$ & Ei-2 & Germany, NR & 2007 & R. Ftayeh \\
\hline C. michiganensis subsp. michiganensis & 3201 & Lu-1 & Germany, KL & 2006 & R. Ftayeh \\
\hline C. michiganensis subsp. michiganensis & 3202 & Mo-1 & Germany, R & 2006 & R. Ftayeh \\
\hline C. michiganensis subsp. michiganensis & $\ldots$ & Мо-2 & Germany, R & 2006 & R. Ftayeh \\
\hline C. michiganensis subsp. michiganensis & 3203 & Sc-2 & Germany, KL & 2006 & R. Ftayeh \\
\hline C. michiganensis subsp. michiganensis & 3204 & BO-RS & Germany, NR & 2006 & R. Ftayeh \\
\hline C. michiganensis subsp. michiganensis & 2972 & $78-\mathrm{s}$ & Germany & 1979 & E. Griesbach \\
\hline C. michiganensis subsp. michiganensis & 3205 & AE-1 & Syria, L & 2007 & R. Ftayeh \\
\hline C. michiganensis subsp. michiganensis & 3206 & AH-1 & Syria, T & 2007 & R. Ftayeh \\
\hline C. michiganensis subsp. michiganensis & $\ldots$ & ES-1 & Syria, $\mathrm{T}$ & 2007 & R. Ftayeh \\
\hline C. michiganensis subsp. michiganensis & 3207 & HH-1 & Syria, L & 2007 & R. Ftayeh \\
\hline C. michiganensis subsp. michiganensis & $\ldots$ & La-1 & Syria, L & 2007 & R. Ftayeh \\
\hline C. michiganensis subsp. michiganensis & 3208 & OS-1 & Austria, STM & 2007 & E. Moltmann \\
\hline C. michiganensis subsp. michiganensis & $\ldots$ & OS-2 & Austria, STM & 2007 & E. Moltmann \\
\hline C. michiganensis subsp. michiganensis & $\ldots$ & OS-4 & Austria, STM & 2007 & E. Moltmann \\
\hline C. michiganensis subsp. michiganensis & 378 & $9 / 79$ & Greece & 1979 & A. Mavridis \\
\hline C. michiganensis subsp. michiganensis & 382 & $24 / 78$ & Greece & 1978 & A. Mavridis \\
\hline C. michiganensis subsp. michiganensis & 390 & $31 / 79$ & Greece & 1979 & A. Mavridis \\
\hline C. michiganensis subsp. michiganensis & 392 & $45 / 78$ & Greece & 1978 & A. Mavridis \\
\hline C. michiganensis subsp. michiganensis & $\ldots$ & Bulgarian 1 & Bulgaria & Unknown & From E. Griesbach \\
\hline C. michiganensis subsp. michiganensis & 2973 & $\mathrm{Cm} 8$ & Bulgaria & Unknown & From E. Griesbach \\
\hline C. michiganensis subsp. michiganensis & 2315 & $\mathrm{KD} / 1-4$ & Turkey & 1994 & Ö. Cinar \\
\hline C. michiganensis subsp. michiganensis & 2221 & NCPPB 1573 & Hungary & 1963 & Z. Klement \\
\hline C. michiganensis subsp. michiganensis & 2222 & NCPPB & Hungary & Unknown & Unknown \\
\hline C. michiganensis subsp. michiganensis & $\ldots$ & 399 & unknown & Unknown & From E. Griesbach \\
\hline C. michiganensis subsp. michiganensis & 3133 & NCPPB 3123 & United States & Unknown & E. Echandi \\
\hline C. michiganensis subsp. michiganensis & $\ldots$ & 185 & United States & Unknown & From E. Griesbach \\
\hline C. michiganensis subsp. michiganensis & $\ldots$ & Leningrad 3 & Russia & Unknown & From E. Griesbach \\
\hline C. michiganensis subsp. insidiosus & 30 & NCPPB 1634 & United Kingdom & 1934 & From Lelliott \\
\hline C. michiganensis subsp. nebraskensis & 2223 & NCPPB 2581 & United States & 1971 & M. L. Schuster \\
\hline C. michiganensis subsp. sepedonicus & 1522 & NCPPB 2140, Cs 1 & United States & 1942 & L.T. Richardson \\
\hline C. michiganensis subsp. sepedonicus & 2823 & Solara 3 & Germany & 1998 & A. Mavridis \\
\hline C. michiganensis subsp. tessellarius & 2224 & ATCC 33566 & United States & 1982 & R. R. Carlson \\
\hline Curtobacterium flaccumfaciens pv. flaccumfaciens & 2218 & NCPPB 559 & United States & 1958 & From Lelliott \\
\hline Bacillus subtilis & 1769 & NCPPB 1246 & United States & 1956 & L. S. Bird \\
\hline B. subtilis & $\ldots$ & FZB 24 & Germany & Unknown & Unknown \\
\hline Pectobacterium subsp. carotovorum & 436 & DSMZ 60442 & Germany & Unknown & Unknown \\
\hline Pantoea agglomerans & 450 & NCPPB 651 & United Kingdom & 1985 & E. Billing \\
\hline Pseudomonas corrugata & 2418 & PC 1 & Germany & 1995 & A. Mavridis \\
\hline P. fluorescens & 1714 & G-1 & Germany & Unknown & Unknown \\
\hline P. syringae pv. syringae & 1142 & $\mathrm{R}-12$ & Germany & 1967 & K. Rudolph \\
\hline P. syringae pv. tomato & 1776 & $14-1$ & Hungary & 1987 & S. Süle \\
\hline P. syringae pv. tomato & 2317 & Nr.-1 & Turkey & 1994 & A. Mavridis \\
\hline P. syringae pv. tomato & $\ldots$ & Syr-1 & Syria & 2007 & R. Ftayeh \\
\hline Ralstonia solanacearum & 2607 & $180 \mathrm{a}$ & Cameroon & 1996 & A. Mavridis \\
\hline R. solanacearum & 2619 & Ps 24 & Brazil & 1995 & O. Martins \\
\hline Xanthomonas arboricola pv. juglandis & 3148 & B- 102 & Germany & 2002 & W. Wohanka \\
\hline X. campestris pv. vesicatoria & 2043 & S-08 & Hungary & 1964 & Z. Klement \\
\hline 22 isolates of saprophytic bacteria ${ }^{\mathrm{e}}$ & $\ldots$ & $\mathrm{S}-1, \mathrm{~S}-2, \ldots, \mathrm{S}-23$ & Germany R, NR, KL & 2006-2007 & R. Ftayeh \\
\hline
\end{tabular}

${ }^{\text {a }}$ GSPB = Göttingen Collection (Sammlung) of Phytopathogenic Bacteria.

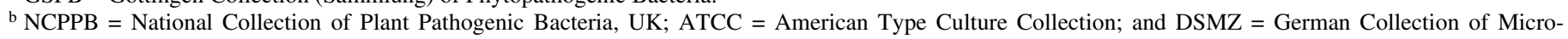
organisms and Cell Cultures.

${ }^{\mathrm{c}} \mathrm{R}=$ Reichenau, NR = Niederrhein, $\mathrm{KL}=$ Knoblauchsland, Franken, $\mathrm{L}=$ Latakia, $\mathrm{T}=$ Tartous, and STM = Steiermark.

$\mathrm{d}$ "From" indicates obtained from the person named.

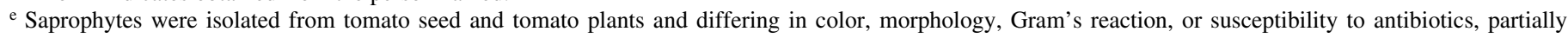
identified by fatty acid analysis. 
Bacterial suspensions containing 25 to $75 \mathrm{CFU}$ were streaked with an "L"-shaped glass rod in triplicate per strain on each test medium. The growth area of each $\mathrm{Cmm}$ strain was determined in square millimeters as the mean of the three replicates on each medium at the third and fifth day after plating (i.e., growth area $=$ number of $\mathrm{CFU} \times \pi r^{2}$ ).

Screening and selection of antibiotics and inhibitors. Forty antibiotics (13) were initially screened on their inhibitory effect against two $\mathrm{Cmm}$ strains. The screening test was performed according to the technique of Bauer et al. (2) by means of commercially available filter discs containing defined concentrations of antibiotics (Oxoid Ltd., England). From these experiments, eight selected antibiotics (aztreonam, fosfomycin metronidazole, mupirocin, nalidixic acid, polymyxin B sulfate, sulfamethoxazole, and trimethoprim) were separately added to NGY agar in different concentrations and tested against $\mathrm{Cmm}$ and 30 accompanying bacterial strains. The accompanying bacteria had been originally isolated from tomato seed and plants (Table 2). High concentrations of the bacterial suspensions were streaked by an inoculation loop onto the test media, and agar plates were incubated at $25^{\circ} \mathrm{C}$. In addition, we tested the inhibitors boric acid, lithium chloride, potassium tellurite, and sodium azide, which are contained in other semiselective media for Cmm. Furthermore, 31 different fungicides (13) were tested in order to select those which inhibit a broad range of fungi occurring on tomato plants without inhibiting $\mathrm{Cmm}$.

Formulation of the optimum concentration of antibiotics. The goal was to determine the optimum concentration of each component in inhibiting nontarget bacteria while allowing good growth of various $\mathrm{Cmm}$ strains. For testing different medium compositions, seed, stems, and side shoots from field-grown tomato plants which had been previously inoculated with an antibiotic-resistant $\mathrm{Cmm}$ strain and which were highly contaminated with saprophytes were homogenized in sterile water and serially diluted. Aliquots of $100 \mu \mathrm{l}$ were streaked in triplicate onto each test composition. The actual number of $\mathrm{Cmm}$ cells contained in the plant homogenates from field trials was determined on NGY agar supplemented with rifampicin at $50 \mathrm{ppm}$, streptomycin at $200 \mathrm{ppm}$, and the fungicide Opus Top at $50 \mu \mathrm{l} / \mathrm{liter}$ (BASF, Ludwigshafen).

Furthermore, homogenates from healthy field plants (collected from different locations in Germany and Syria) were surface streaked in triplicate onto NGY agar and test compositions in order to estimate selectivity. In parallel, suspensions of two $\mathrm{Cmm}$ strains (GSPB 390 and GSPB 2973) differing in growth morphology and speed were also streaked, each in triplicate, onto agar plates with NGY or test compositions to estimate the growth area of Cmm. Only those compositions which allowed high selectivity concomitantly with large growth areas of $\mathrm{Cmm}$ were selected and modified repeatedly in further experiments.

Naturally infected or spiked plant and seed samples. New medium compositions were tested with healthy and infected tomato plants and seed harvested from field trials in Göttingen. In addition, samples from naturally infected tomato plants obtained from different locations in Germany, Austria, and Syria were included to enlarge the diversity of epiphytic microorganisms which might interfere with $\mathrm{Cmm}$ growth on the test media. For inoculation of field plants in 2007 and 2008, Cmm strain BO-RS (GSPB 3204), with resistance against rifampicin and streptomycin, was used. Four-month-old field plants were inoculated by stabbing the stem with a fine needle through a drop of a bacterial

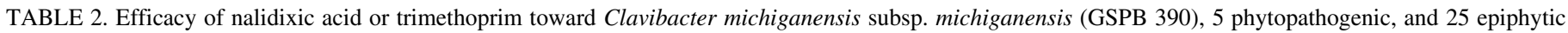

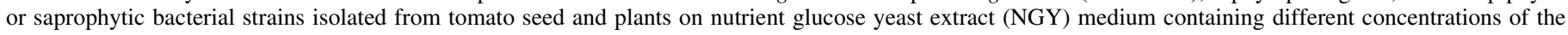
two antibiotics

\begin{tabular}{|c|c|c|c|c|c|c|c|c|c|}
\hline \multirow[b]{3}{*}{ Bacterial species or strain ${ }^{a}$} & \multirow[b]{3}{*}{ Gram reaction $^{\mathrm{b}}$} & \multirow[b]{3}{*}{ Colony color on NGY } & \multicolumn{7}{|c|}{ Bacterial growth on NGY amended with ${ }^{c}$} \\
\hline & & & \multicolumn{4}{|c|}{ Nalidixic acid } & \multicolumn{3}{|c|}{ Trimethoprim } \\
\hline & & & 5 & 10 & 20 & 50 & 100 & 200 & 300 \\
\hline C. michiganensis subsp. michiganensis (GSPB 390) & $\mathrm{G}+$ & Typical & + & + & + & \pm & + & + & + \\
\hline Xanthomonas juglandis (GSPB 3148) & $\mathrm{G}-$ & Typical & + & + & - & - & + & - & - \\
\hline X. campestris pv. vesicatoria (GSPB 2043) & $\mathrm{G}-$ & Typical & + & + & - & - & + & - & - \\
\hline Pseudomonas syringae pv. syringae (GSPB 1142) & $\mathrm{G}-$ & Typical & - & - & - & - & + & - & - \\
\hline P. syringae pv. tomato (GSPB 2317) & $\mathrm{G}-$ & Typical & - & - & - & - & + & - & - \\
\hline P. fluorescens (GSPB 1714) & $\mathrm{G}-$ & Typical & \pm & - & - & - & + & - & - \\
\hline Pantoea agglomerans (GSPB 450) & $\mathrm{G}-$ & Typical & \pm & - & - & - & + & - & - \\
\hline Pectobacterium subsp. carotovorum (GSPB 436) & $\mathrm{G}-$ & Typical & + & + & + & - & - & - & - \\
\hline Bacillus subtilis (GSPB 1769) & $\mathrm{G}+$ & Typical & - & - & - & - & - & - & - \\
\hline S-1: Pseudomonas putida & $\mathrm{G}-$ & White creamy & - & - & - & - & + & - & - \\
\hline S-2: Microbacterium lacticum & $\mathrm{G}+$ & Yellow-pink & + & + & + & - & - & - & - \\
\hline S-3: not determined & $\mathrm{G}-$ & Dark yellow & - & - & - & - & - & - & - \\
\hline S-4: Pantoea sp. & $\mathrm{G}-$ & Creamy yellowish & + & + & \pm & - & - & - & - \\
\hline S-5: Pantoea sp. & $\mathrm{G}-$ & White yellowish & + & + & - & - & - & - & - \\
\hline S-7: not determined & $\mathrm{G}+$ & Creamy & + & + & + & - & - & - & - \\
\hline S-8: B. cereus & $\mathrm{G}+$ & Yellow & + & + & + & + & - & - & - \\
\hline S-9: not determined & $\mathrm{G}-$ & White-creamy & + & + & + & + & + & - & - \\
\hline S-10: Pseudomonas syringae & $\mathrm{G}-$ & White-creamy & \pm & - & - & - & + & - & - \\
\hline S-11: B. coagulans & $\mathrm{G}+$ & Light yellow-pink & + & + & + & - & \pm & - & - \\
\hline S-12: Microbacterium sp. & $\mathrm{G}+$ & Pink-yellowish & + & + & + & - & - & - & - \\
\hline S-13: Pantoea agglomerans & $\mathrm{G}-$ & Light yellow & - & - & - & - & + & - & - \\
\hline S-14: Pseudomonas putida & $\mathrm{G}-$ & White creamy & + & \pm & - & - & + & \pm & \pm \\
\hline S-15: P. putida & $\mathrm{G}-$ & White creamy & + & - & - & - & + & \pm & \pm \\
\hline S-16: not determined & $\mathrm{G}+$ & Violet & - & - & - & - & - & - & - \\
\hline S-17: not determined & $\mathrm{G}+$ & Dark orange & + & - & - & - & + & \pm & - \\
\hline S-18: not determined & $\mathrm{G}-$ & Yellow & - & - & - & - & - & - & - \\
\hline S-19: Rahnella aquatilis & $\mathrm{G}-$ & White & - & - & - & - & + & - & - \\
\hline S-20: not determined & $\mathrm{G}+$ & Dark yellow & + & - & - & - & + & - & - \\
\hline S-21: B. licheniformis & $\mathrm{G}+$ & Light yellow, creamy & + & + & + & - & - & - & - \\
\hline S-22: not determined & $\mathrm{G}+$ & White & - & - & - & - & - & - & - \\
\hline S-23: B. pumilus & $\mathrm{G}+$ & Yellow & + & + & \pm & - & - & - & - \\
\hline
\end{tabular}

${ }^{a}$ GSPB $=$ Göttingen Collection (Sammlung) of Phytopathogenic Bacteria.

${ }^{\mathrm{b}} \mathrm{G}-=$ gram negative and $\mathrm{G}+=$ gram positive.

c Antibiotic concentrations in milligrams per liter; $+=$ growth, $-=$ no growth, and $\pm=$ slight growth. 
suspension ( 30 to $50 \mu \mathrm{l}$ containing 30 to $50 \mathrm{CFU}$ of $\mathrm{Cmm}$ ) placed in the axil of the fourth or fifth true leaf. Two months later, tomato seed were extracted with water, dried, and stored at $4^{\circ} \mathrm{C}$ for maintaining accompanying bacterial populations. In addition, stems of inoculated and noninoculated (control) plants were cut and stored at $-20^{\circ} \mathrm{C}$ until use.

In case of using healthy field plants that were highly contaminated with epiphytic bacteria, defined low amounts of Cmm cells were added to the homogenates ("spiked") directly before surface plating onto test media.

Criteria for evaluating semiselective media. Three parameters were determined for evaluation of BCT and the published semiselective media: (i) plating efficiency (recovery rate) $(\%)=$ (CFU of $\mathrm{Cmm}$ on test medium/CFU of $\mathrm{Cmm}$ on NGY) $\times 100$; (ii) selectivity $(\%)=[($ Population of nontarget microbes on NGY - population of nontarget microbes on test medium)/population of nontarget microbes on $\mathrm{NGY}] \times 100$; and (iii) detection sensitivity = lowest number of $\mathrm{Cmm}$ CFU occurring in plant homogenates which could be detected in the presence of high concentrations of nontarget bacteria.

\section{RESULTS}

Development of the basal medium for $\mathbf{C m m}$. The highest growth of $\mathrm{Cmm}$ was recorded on the basal medium of MTNA after 3 and 5 days (Fig. 1). Therefore, this composition was selected and further adapted to $\mathrm{Cmm}$ by several modifications.

Screening and selection of antibiotics or inhibitors. From the eight selected antibiotics, only a combination of nalidixic acid and trimethoprim suppressed all nontarget bacteria tested (Table 2). Polymyxin B sulfate was tested separately and also showed a broad inhibitory efficacy on accompanying bacteria. From the inhibitors tested, only boric acid was selected, whereas lithium chloride, potassium tellurite, and sodium azide did not improve the medium. Finally, the selected components were tested in multiple combinations in the modified basal medium of MTNA. After each experimental block, the variants showing the highest potential for $\mathrm{Cmm}$ growth speed combined with a good selectivity were chosen and modified repeatedly until the optimal final composition of the new medium was achieved.

Recipe of the new medium BCT. For 1 liter of deionized water add: $2.5 \mathrm{~g}$ mannitol (Merck, Darmstadt, Germany), $2.0 \mathrm{~g}$ yeast extract (Roth), $1.0 \mathrm{~g} \mathrm{~K}_{2} \mathrm{HPO}_{4}, 0.1 \mathrm{~g} \mathrm{KH}_{2} \mathrm{PO}_{4}, 0.05 \mathrm{~g} \mathrm{NaCl}$,

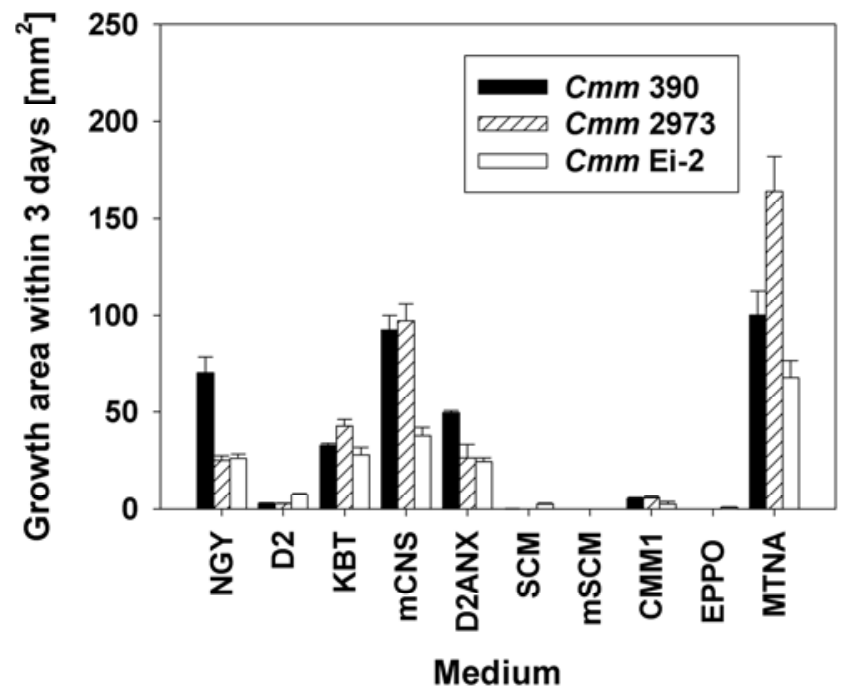

$0.1 \mathrm{~g} \mathrm{MgSO}_{4} \times 7 \mathrm{H}_{2} \mathrm{O}, 0.015 \mathrm{~g} \mathrm{MnSO}_{4} \times \mathrm{H}_{2} \mathrm{O}, 0.015 \mathrm{~g} \mathrm{FeSO}_{4} \times$ $7 \mathrm{H}_{2} \mathrm{O}$, and $0.6 \mathrm{~g} \mathrm{H}_{3} \mathrm{BO}_{3}$. The resulting $\mathrm{pH}$ should be between 7.0 to 7.1. Add $15 \mathrm{~g} /$ liter agar (Roth). After autoclaving at $121^{\circ} \mathrm{C}$ for $15 \mathrm{~min}$ and cooling at 50 to $55^{\circ} \mathrm{C}$ under stirring, add per liter: $20 \mathrm{mg}$ nalidixic acid (AppliChem), $100 \mathrm{mg}$ trimethoprim (Fluka), $20 \mathrm{mg}$ polymyxin B sulfate $(8,120$ international units/mg) (AppliChem), and $50 \mu \mathrm{l}$ of the fungicide Opus Top (BASF) containing epoxiconazole at $84 \mathrm{~g} /$ liter and fenpropimorph at $250 \mathrm{~g} /$ liter.

Antibiotics and Opus Top should be added as stock solutions, freshly prepared, and kept sterile at $4^{\circ} \mathrm{C}$. Stock solutions contain: nalidixic acid $(20 \mathrm{mg} / \mathrm{ml}$ of $0.01 \mathrm{~N} \mathrm{NaOH}$, filter-sterilized), trimethoprim $(50 \mathrm{mg} / \mathrm{ml}$ of dimethyl sulfoxide, kept in the dark), polymyxin B sulfate $(10 \mathrm{mg} / \mathrm{ml}$ of water, filter-sterilized $)$, and Opus Top ( $50 \mu \mathrm{l} / \mathrm{ml}$ sterile water).

Effect of boric acid. Depending on the concentration of boric acid contained in the NGY medium or the new basal media, the inhibition of saprophytic bacteria was increased but the growth of $\mathrm{Cmm}$ was retarded (data not shown). However, when antibiotics were added to the new basal media, the effect of boric acid on $\mathrm{Cmm}$ was the opposite. By adding boric acid, the recovery rate of $\mathrm{Cmm}$ remained at a high level, even when high amounts of antibiotics were added (Fig. 2). Further experiments revealed that this effect was due to an interaction between boric acid and polymyxin B sulfate (Fig. 3). Surprisingly, the toxic effect of polymyxin B sulfate toward $\mathrm{Cmm}$ was significantly reduced by boric acid, whereas this effect was not observed toward the accompanying bacteria occurring in seed and plant homogenates. Thus, by discovering this interaction between boric acid and polymyxin B sulfate, it was possible to develop the new medium BCT that permits a high selectivity and, concomitantly, a high plating efficiency of $\mathrm{Cmm}$.

Plating efficiency (recovery rate) of $\mathrm{Cmm}$ strains on 10 semiselective media. Bacterial suspensions of $30 \mathrm{Cmm}$ strains containing 100 to $250 \mathrm{CFU}$ were plated in triplicate for each strain onto test media and incubated at $26^{\circ} \mathrm{C}$. To avoid counting errors by the possible merging of several joining colonies, counting of $\mathrm{Cmm}$ colonies was started as soon as possible on each medium (for example, on NGY after 48 to $72 \mathrm{~h}$ ). Plating efficiency of each strain after 7, 10, 15, and 20 days was expressed as percent CFU compared with CFU on NGY agar. Summarized and individual data (Fig. 4; Table 3) show that only four media (D2, SCM, CMM1, and BCT) allowed a plating efficiency similar to that of the nonselective NGY medium. All $\mathrm{Cmm}$ strains grew on

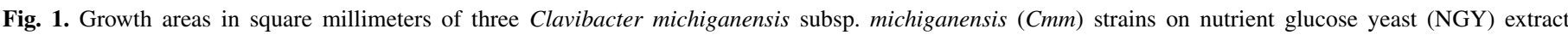

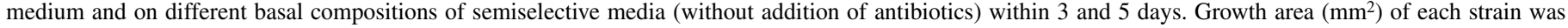

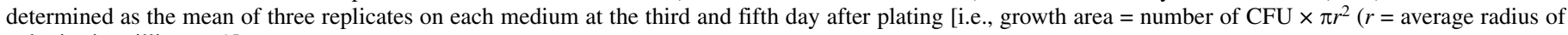
colonies in millimeters)].

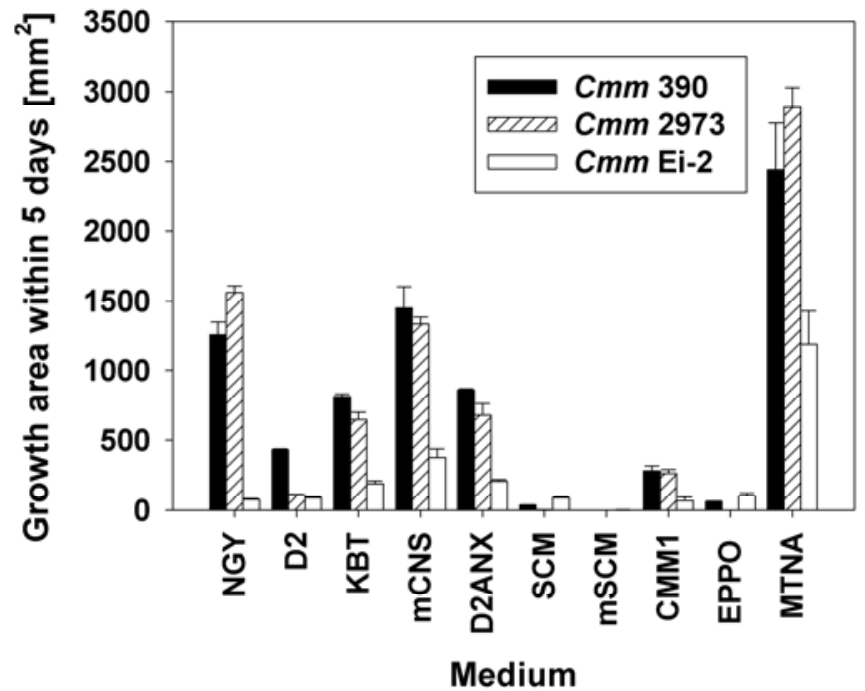


NGY within 3 days, and most $\mathrm{Cmm}$ strains tested started to grow on the new selective medium BCT on the fourth or fifth day after plating. Finally, 29 of the 30 strains tested grew on the new medium within the first 7 days. One $\mathrm{Cmm}$ strain took 7 to 10 days to grow on BCT and did not grow on BCT-2. On BCT, colony diameter of $\mathrm{Cmm}$ was 2.0 to $5.0 \mathrm{~mm}$ within 7 days.

Selectivity of the new medium BCT. All 42 nontarget bacterial species and pathovars tested were unable to grow on BCT but grew very well on NGY or KB. These bacterial strains included Bacillus subtilis, Pantoea agglomerans, Pectobacterium carotovorum subsp. carotovorum, Pseudomonas corrugata, $P$. fluorescens, $P$. syringae pv. syringae, $P$. syringae pv. tomato, Ralstonia solanacearum, Xanthomonas arboricola pv. juglandis, $X$. campestris pv. vesicatoria, and 22 different saprophytic bacterial isolates from tomato plants (Table 2, S-1 to S-23). In contrast to the nontarget bacterial strains, all $30 \mathrm{Cmm}$ strains tested grew on BCT and 29 of 30 strains grew on BCT-2.

Further experiments with homogenates from field tomato plants and seed containing extremely high levels of naturally occurring accompanying bacteria and which were spiked with low $\mathrm{Cmm}$ populations showed a high selectivity of BCT, because an average of $98.5 \%$ of nontarget bacterial populations did not grow on BCT (Table 4) and the remaining colonies of nontarget bacteria were rather small and easily distinguishable from the larger Cmm colonies (Fig. 5). All eight published semiselective media for $\mathrm{Cmm}$ revealed false-negative results under these extreme conditions (i.e., the added $\mathrm{Cmm}$ bacteria could not be visually detected, even after restreaking and microscopic tests of suspected colonies).

Detection sensitivity of the semiselective media. Stem sections of 1 to $2 \mathrm{~cm}$ from field tomato plants were crushed in sterile mortars with 5 to $8 \mathrm{ml}$ of sterile water, or 10 to 25 seeds from field plants were crushed in 1 to $2 \mathrm{ml}$ of sterile water. Serial dilutions in $0.01 \mathrm{M} \mathrm{MgSO}_{4}$ were surface plated on test media and incubated at $26^{\circ} \mathrm{C}$. Counting nontarget bacteria was started as soon as colonies became visible, and the final counts recorded at 7 to 10 days for semiselective media were compared with bacterial populations recovered on NGY medium within 1 to 4 days. These results were confirmed by repeated streaking of suspected $\mathrm{Cmm}$ colonies on NGY agar plates, a microscopic check, and Gram reaction. Even as few as $8 \mathrm{CFU}$ of $\mathrm{Cmm}$ among 12,750 saprophytes or $58 \mathrm{CFU}$ of $\mathrm{Cmm}$ among $18,000 \mathrm{CFU}$ of saprophytes from plant homogenates streaked onto one petri plate revealed positive results (Table 4), although not every single CFU

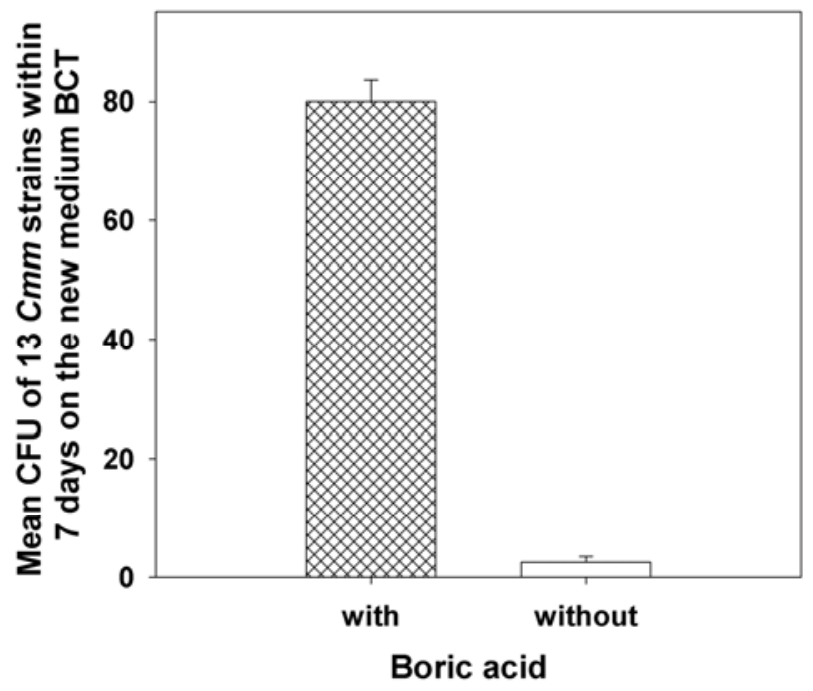

Fig. 2. Mean number of CFU per plate recovered from pure cultures of 13 Clavibacter michiganensis subsp. michiganensis $(\mathrm{Cmm})$ strains (each in three replicates) on the new medium (BCT) with and without boric acid, when $\approx 90$ $\mathrm{CFU}$ were streaked on each petri dish. could be recovered. Thus, 25 to $100 \%$ of the existing Cmm cells added to or contained in plant and seed homogenates were detected on BCT. In contrast, none of the earlier published semiselective media resulted in the detection of $\mathrm{Cmm}$ under these extreme conditions.

In other experiments when the differences in population densities between saprophytes and $\mathrm{Cmm}$ were lower, by increasing the amounts of $\mathrm{Cmm}$ in plant homogenates or by reducing amounts of saprophytic bacteria in dilutions, detection of $\mathrm{Cmm}$ was possible on some of the published media; however, distinguishing between $\mathrm{Cmm}$ and saprophytes was often difficult. In fact, on these published semiselective media, $\mathrm{Cmm}$ colonies could not always be distinguished from contaminants, particularly (i) if certain $\mathrm{Cmm}$ strains did not show the typical colony morphology as known from those media, or (ii) when the morphology of some saprophytic bacteria was similar to $\mathrm{Cmm}$, resulting in confusions with some saprophytes. In contrast, on BCT, $\mathrm{Cmm}$ colonies were clearly distinguishable from saprophytes once they had increased in colony size with time, whereas saprophytic bacteria remained smaller due to selective inhibition and were mostly white in color (Fig. 5). In contrast, Cmm colonies were shining, convex, slimy, and more or less circular and the color varied from white creamy to yellow (Fig. 6).

Modifications of BCT. BCT was modified into BCT-2 by increasing the phosphate concentration $\left(\mathrm{K}_{2} \mathrm{HPO}_{4}\right.$ at $2.0 \mathrm{~g} / \mathrm{liter}$ and $\mathrm{KH}_{2} \mathrm{PO}_{4}$ at $0.5 \mathrm{~g} /$ liter). The resulting $\mathrm{pH}$ value of BCT-2 should be 7.2. While BCT supported growth of all $30 \mathrm{Cmm}$ strains tested, and most of the $\mathrm{Cmm}$ strains started to grow after 4 to 5 days, BCT-2 supported growth of $29 \mathrm{Cmm}$ strains and growth was 1 day delayed (Table 3). However, the detection sensitivity of $\mathrm{Cmm}$ cells spiked into seed and plant extracts was greater on BCT than on BCT-2, apparent by the larger colony size of $\mathrm{Cmm}$ on BCT (Table 4).

Opus Top was selected out of 31 fungicides tested because of its high efficacy toward a wide range of fungi and its antimicrobial effect against some saprophytic bacteria (data not shown). From these fungicides, only cycloheximde or nystatin are contained in the published semiselective media for $\mathrm{Cmm}$. However, both fungicides did not suppress fungal growth on agar media as effectively as Opus Top. Opus Top also showed an antimicrobial

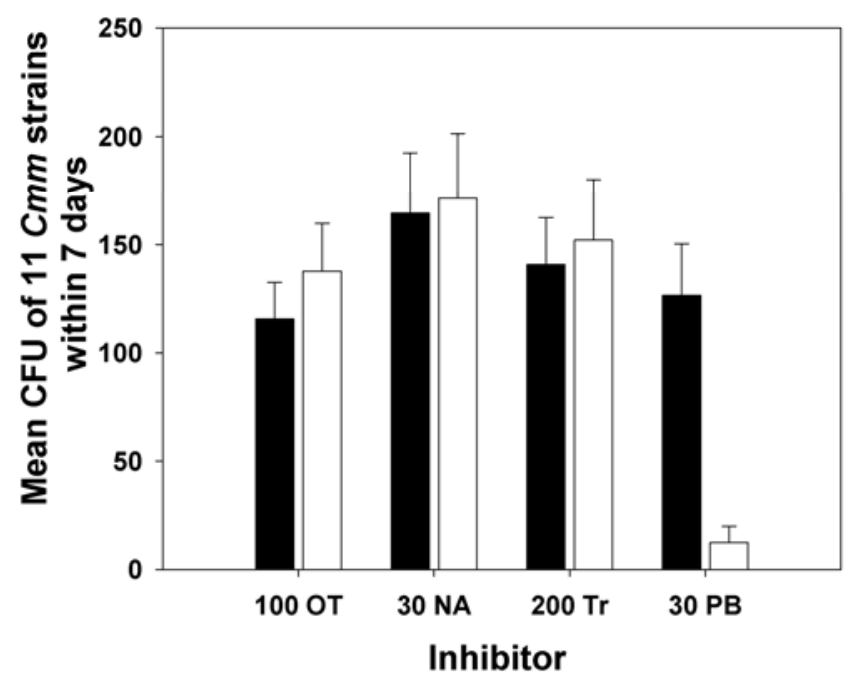

With boric acid $\square$ Without boric acid

Fig. 3. Interactive effects of boric acid with different inhibitors in the basal medium of BCT on the growth of Clavibacter michiganensis subsp. michiganensis ( Cmm) (data represent the mean of $11 \mathrm{Cmm}$ strains, each in three replicates), $100 \mathrm{OT}=$ Opus Top at $100 \mu \mathrm{l} / \mathrm{liter}, 30 \mathrm{NA}=$ nalidixic acid at 30 ppm, $200 \mathrm{Tr}=$ trimethoprim at $200 \mathrm{ppm}$, and $30 \mathrm{~PB}=$ polymyxin B sulfate at $30 \mathrm{ppm}(8,120 \mathrm{IU} / \mathrm{mg})$. 
effect against some saprophytic bacteria without inhibiting $\mathrm{Cmm}$. Thus, by replacing Opus Top with cycloheximide or nystatin in BCT or BCT-2, growth and recovery rates of $\mathrm{Cmm}$ were increased but the selectivity was reduced, even when antibiotic concentrations were increased (13). Therefore, it is not recommended to replace Opus Top with other fungicides.

Selectivity of BCT for other pathovars or species of coryneform bacteria. In additional experiments, we tested the suitability of BCT for detection of other coryneform phytopathogenic bacteria (Table 5). The results revealed that only those bacteria which are very closely related to $\mathrm{Cmm}$ according to Davis et al. (8) (i.e., the $C$. michiganensis subsp. tessellarius, insidiosus, and nebraskensis) grew exclusively on the new selective medium BCT (Table 5).

The colony appearance of the three subspecies on BCT was quite distinct within 7 days. C. michiganensis subsp. tessellarius (Fig. 7A) had light pink, shining, and slimy colonies with a diameter of 1.5 to $2.5 \mathrm{~mm}$; C. michiganensis subsp. insidiosus (Fig. 7B) had small, pink colonies with violet internal flecks and a diameter of 1.0 to $1.8 \mathrm{~mm}$; and $C$. michiganensis subsp. nebraskensis: colonies were similar to $\mathrm{Cmm}$ (i.e., large, yellow, shining, slimy colonies with a diameter of 2.0 to $3.0 \mathrm{~mm}$ ).

\section{DISCUSSION}

Recently, bacterial canker of tomato has emerged on tomato crops growing on sterilized artificial substrate in some European countries for the first time (personal observation). These disease outbreaks suggest seed as the source of inoculum even though the seed had been certified as healthy according to the EPPO (27) and ISHI (22) detection protocols. Thus, questions arose about the reliability of the currently applied protocols for seed health testing, especially the protocols that are based on plating assays of seed extracts on semiselective media recommended by the EPPO (27) or by the ISHI (22). The earlier reported semiselective media for $\mathrm{Cmm}$ do not permit an acceptable balance between high plating efficiency and high selectivity. Thus, several earlier published semiselective media for $\mathrm{Cmm}$ proved to allow high plating efficiencies (D2, KBT, SCM, CMM1, and D2ANX) in our experiments, but these media failed to strongly suppress nontarget bacteria that inhibited growth and detection of $\mathrm{Cmm}$. In case of high inhibition of the accompanying bacteria by semiselective media (mSCM, EPPO, and mCNS), this feature was due to a general toxicity, so that many $\mathrm{Cmm}$ strains also failed to grow on these media. Hadas and co-workers (19) obtained similar results,
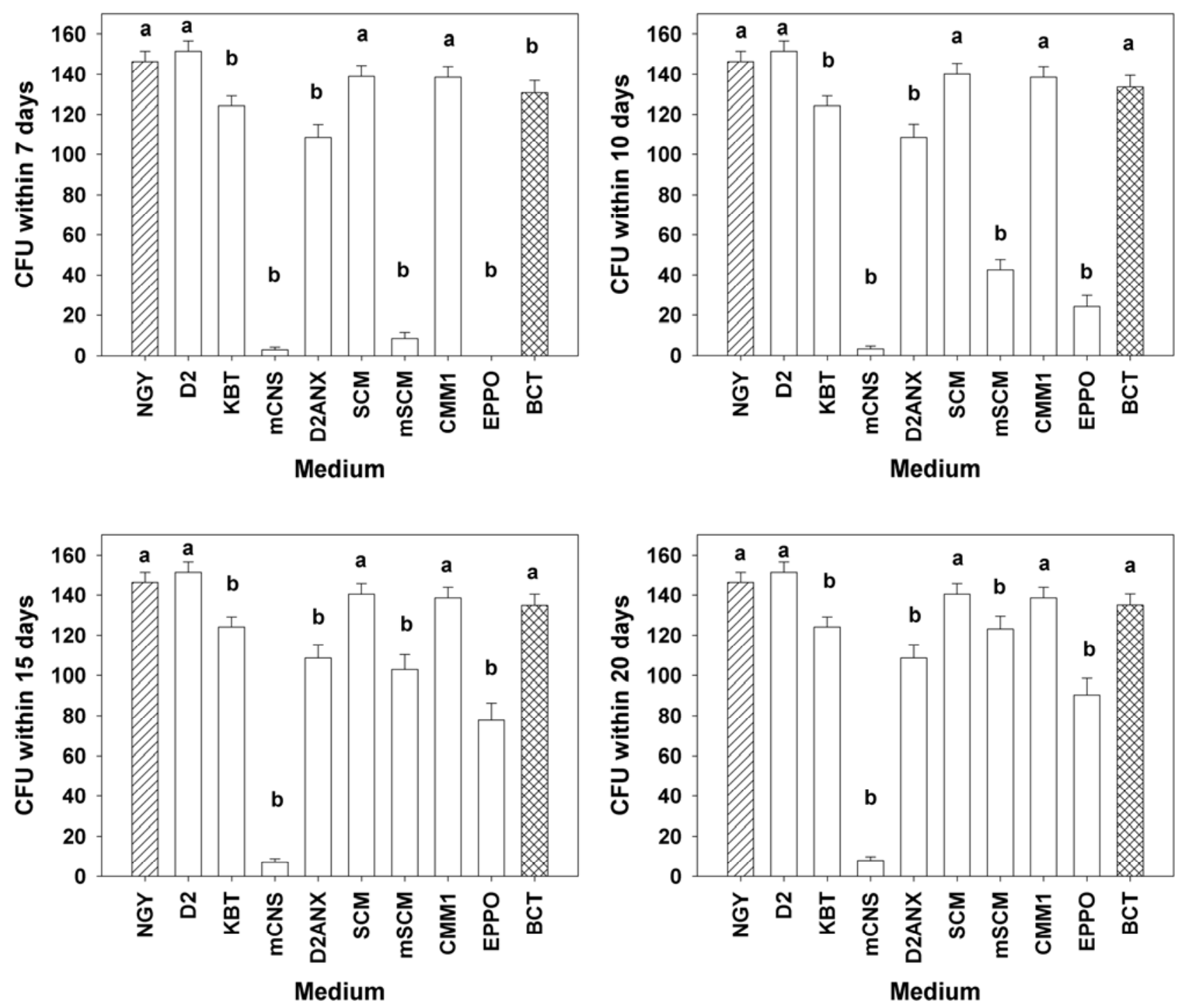

Fig. 4. Recovery of Clavibacter michiganensis subsp. michiganensis $(\mathrm{Cmm})$ on nine semiselective media and on the nonselective medium nutrient glucose yeast extract (NGY). Results were obtained from single experiments with $30 \mathrm{Cmm}$ strains. Each column represents the mean of $30 \mathrm{Cmm}$ strains, each in triplicate. Starting inocula contained 100 to $250 \mathrm{CFU}$ per strain and plate. The same letter (a) above columns indicates no significant difference to the standard nonselective NGY medium. Statistical analysis was performed by Fisher's least significant difference test. $P \leq 0.05, n=900$. 
because some of their $\mathrm{Cmm}$ strains tested were not able to grow on D2ANX, CNS, or mSCM, and other $\mathrm{Cmm}$ strains grew with very low plating efficiency. Thus, a sensitive detection with a very low threshold was impossible to reach with any of these earlier published semiselective media. Therefore, an increased effort to improve the detection sensitivity of the pathogen in seed and transplants has been suggested $(21,28)$.

Development of an absolute synthetic selective medium for $\mathrm{Cmm}$ was impossible because of its partial fastidious nature. Therefore, we included yeast extract serving as nitrogen and carbon source. The main carbon source of BCT is D (-) mannitol, whereas previous semiselective media used glucose, sucrose, or mannose.
However, mannitol is more selective than glucose and sucrose, the growth of $\mathrm{Cmm}$ is well supported, and mannitol is more heat stable than glucose. Mannose is also selective but it does not reliably support growth of $\mathrm{Cmm}$. These results are similar to those of De la Cruz (9) and Jansing and Rudolph (20) in the case of the closely related pathogen $C$. michiganensis subsp. sepedonicus.

The main problem in designing a selective medium for $\mathrm{Cmm}$ was to find the optimum combination and dosage of antibiotics and inhibitors, because (i) great differences among $\mathrm{Cmm}$ strains in sensitivity toward antibiotics and inhibitors, and (ii) the finding that some nontarget bacteria occurring on tomato plants and seed were more tolerant toward antibiotics and inhibitors than $\mathrm{Cmm}$.

TABLE 3. Plating efficiency of 30 Clavibacter michiganensis subsp. michiganensis (Cmm) strains on 10 semiselective media, expressed as percent CFU compared with the nonselective nutrient glucose yeast extract (NGY) medium ${ }^{\mathrm{a}}$

\begin{tabular}{|c|c|c|c|c|c|c|c|c|c|c|}
\hline \multirow[b]{2}{*}{ Strain } & \multicolumn{10}{|c|}{ Plating efficiency $(\%)$ within $7 / 10 / 15 / 20$ days, respectively, on } \\
\hline & D2 & KBT & $\mathrm{mCNS}$ & D2ANX & $\mathrm{SCM}$ & $\mathrm{mSCM}$ & CMM1 & EPPO & $\mathrm{BCT}$ & BCT-2 \\
\hline Amb-1 & $117 / 117 / 117 / 117$ & $120 / 120 / 120 / 120$ & 0/0/0/0 & 61/61/61/61 & $125 / 125 / 125 / 125$ & $0 / 0 / 86 / 113$ & $109 / 109 / 109 / 109$ & $0 / 0 / 0 / 0$ & $67 / 90 / 90 / 90$ & 76/76/90/90 \\
\hline Ei-1 & $121 / 121 / 121 / 121$ & $123 / 123 / 123 / 123$ & $0 / 0 / 1 / 1$ & $104 / 104 / 104 / 104$ & $119 / 119 / 119 / 119$ & 0/0/101/103 & $106 / 106 / 106 / 106$ & $0 / 0 / 19 / 43$ & $87 / 109 / 109 / 109$ & $119 / 119 / 119 / 119$ \\
\hline $\mathrm{Ei}-2$ & $110 / 110 / 110 / 110$ & 95/95/95/95 & 0/0/0/0 & $13 / 13 / 13 / 13$ & 94/94/94/94 & 0/84/84/96 & 89/89/89/89 & 0/0/0/0 & 73/73/73/73 & 98/98/98/98 \\
\hline Lu-1 & $127 / 127 / 127 / 127$ & 92/92/92/92 & $0 / 0 / 0 / 0$ & 98/98/98/98 & $94 / 94 / 94 / 94$ & 0/69/69/98 & $105 / 105 / 105 / 105$ & 0/0/0/0 & $102 / 102 / 102 / 102$ & $114 / 114 / 114 / 114$ \\
\hline Mo-1 & $112 / 112 / 112 / 112$ & $89 / 89 / 89 / 89$ & $47 / 47 / 51 / 51$ & 91/91/91/91 & $105 / 105 / 105 / 105$ & $0 / 0 / 113 / 113$ & 93/93/93/93 & $0 / 0 / 104 / 104$ & 96/96/96/96 & 97/97/97/97 \\
\hline Mo-2 & $103 / 103 / 103 / 103$ & $103 / 103 / 103 / 103$ & $0 / 0 / 3 / 6$ & 90/90/90/90 & $104 / 104 / 104 / 104$ & $0 / 51 / 85 / 102$ & $111 / 111 / 111 / 111$ & $0 / 0 / 0 / 2$ & 95/95/95/95 & $87 / 87 / 87 / 87$ \\
\hline $\mathrm{Sc}-1$ & $112 / 112 / 112 / 112$ & $106 / 106 / 106 / 106$ & $0 / 0 / 3 / 6$ & 90/90/90/90 & $107 / 107 / 107 / 107$ & $0 / 35 / 86 / 95$ & $108 / 108 / 108 / 108$ & $0 / 0 / 0 / 0$ & $112 / 112 / 112 / 112$ & $110 / 110 / 110 / 110$ \\
\hline BO-RS & 91/91/91/91 & $68 / 68 / 68 / 68$ & $0 / 0 / 0 / 0$ & $36 / 36 / 36 / 36$ & $25 / 35 / 35 / 35$ & $0 / 0 / 0 / 0$ & $67 / 67 / 67 / 67$ & $0 / 0 / 0 / 0$ & $76 / 76 / 76 / 76$ & 71/71/71/71 \\
\hline GSPB 2972 & $84 / 84 / 84 / 84$ & $61 / 61 / 61 / 61$ & $0 / 0 / 0 / 0$ & $107 / 107 / 107 / 107$ & $80 / 80 / 80 / 80$ & $0 / 0 / 0 / 0$ & 97/97/97/97 & $0 / 0 / 0 / 57$ & $92 / 92 / 92 / 92$ & $81 / 81 / 88 / 88$ \\
\hline AE-1 & $112 / 112 / 112 / 112$ & $87 / 87 / 87 / 87$ & $0 / 0 / 0 / 0$ & $56 / 56 / 56 / 56$ & $102 / 102 / 102 / 102$ & $0 / 10 / 24 / 38$ & $94 / 94 / 94 / 94$ & $0 / 12 / 12 / 21$ & $106 / 106 / 106 / 106$ & $94 / 94 / 94 / 94$ \\
\hline $\mathrm{AH}-1$ & $117 / 117 / 117 / 117$ & $114 / 114 / 114 / 114$ & 0/0/0/0 & $89 / 89 / 89 / 89$ & $107 / 107 / 107 / 107$ & $0 / 44 / 77 / 89$ & $118 / 118 / 118 / 118$ & $0 / 111 / 111 / 122$ & $100 / 100 / 100 / 100$ & $68 / 68 / 68 / 68$ \\
\hline ES-1 & 98/98/98/98 & 90/90/90/90 & $0 / 0 / 0 / 0$ & 95/95/95/95 & $100 / 100 / 100 / 100$ & 0/0/99/99 & 90/90/90/90 & 0/0/92/92 & 93/93/93/93 & 79/79/79/79 \\
\hline $\mathrm{HH}-1$ & 109/109/109/109 & 99/99/99/99 & $0 / 0 / 4 / 5$ & $75 / 75 / 75 / 75$ & $104 / 104 / 104 / 104$ & 0/76/77/79 & $86 / 86 / 86 / 86$ & $0 / 0 / 0 / 0$ & $45 / 45 / 45 / 45$ & $107 / 107 / 107 / 107$ \\
\hline La-1 & 96/96/96/96 & $64 / 64 / 64 / 64$ & $0 / 0 / 0 / 0$ & $43 / 43 / 43 / 43$ & $89 / 89 / 89 / 89$ & 71/79/87/88 & $89 / 89 / 89 / 89$ & 0/87/87/91 & $87 / 87 / 87 / 87$ & 73/73/73/73 \\
\hline OS-1 & 93/93/93/93 & $74 / 74 / 74 / 74$ & $0 / 0 / 4 / 4$ & 93/93/93/93 & $101 / 101 / 101 / 101$ & 0/0/99/99 & $94 / 94 / 94 / 94$ & $0 / 0 / 79 / 84$ & 96/96/96/96 & 93/93/93/93 \\
\hline OS-2 & 91/91/91/91 & $84 / 84 / 84 / 84$ & $0 / 0 / 0 / 0$ & $81 / 81 / 81 / 81$ & $129 / 129 / 129 / 129$ & 0/0/103/105 & 91/91/91/91 & $0 / 0 / 65 / 73$ & 91/91/91/91 & 93/93/93/93 \\
\hline OS-4 & 91/91/91/91 & $87 / 87 / 87 / 87$ & 0/0/0/0 & $47 / 47 / 47 / 47$ & $120 / 120 / 120 / 120$ & 0/89/89/101 & 91/91/91/91 & 0/0/0/10 & 109/109/109/109 & $83 / 83 / 83 / 83$ \\
\hline GSPB 378 & $88 / 88 / 88 / 88$ & $88 / 88 / 88 / 88$ & $0 / 0 / 0 / 0$ & $43 / 43 / 43 / 43$ & 93/93/93/93 & 0/76/98/98 & $75 / 75 / 75 / 75$ & $0 / 79 / 87 / 88$ & $66 / 66 / 66 / 66$ & $81 / 81 / 81 / 81$ \\
\hline GSPB 382 & $83 / 83 / 83 / 83$ & $55 / 55 / 55 / 55$ & $0 / 0 / 0 / 0$ & $0 / 0 / 0 / 0$ & $65 / 65 / 65 / 65$ & $48 / 67 / 67 / 67$ & $49 / 49 / 49 / 49$ & $0 / 65 / 65 / 66$ & $45 / 45 / 45 / 45$ & $20 / 42 / 46 / 46$ \\
\hline GSPB 390 & $111 / 111 / 111 / 111$ & $102 / 102 / 102 / 102$ & $0 / 0 / 0 / 0$ & $85 / 85 / 85 / 85$ & $88 / 88 / 88 / 88$ & $0 / 76 / 76 / 93$ & $103 / 103 / 103 / 103$ & $0 / 113 / 113 / 116$ & $108 / 108 / 108 / 108$ & $111 / 111 / 111 / 111$ \\
\hline GSPB 392 & $106 / 106 / 106 / 106$ & 91/91/91/91 & $0 / 0 / 0 / 1$ & $72 / 72 / 72 / 72$ & $92 / 92 / 92 / 92$ & $0 / 0 / 115 / 115$ & 96/96/96/96 & $0 / 0 / 113 / 113$ & $102 / 102 / 102 / 102$ & $107 / 107 / 107 / 107$ \\
\hline Bulgarian 1 & 97/97/97/97 & $104 / 104 / 104 / 104$ & $0 / 0 / 0 / 0$ & 79/79/79/79 & $103 / 103 / 103 / 103$ & $0 / 85 / 102 / 102$ & $87 / 87 / 87 / 87$ & 0/0/96/96 & $0 / 23 / 58 / 64$ & 0/0/0/0 \\
\hline GSPB 2973 & 94/94/94/94 & 99/99/99/99 & $0 / 7 / 9 / 9$ & 94/94/94/94 & $82 / 82 / 82 / 82$ & $0 / 0 / 0 / 46$ & $100 / 100 / 100 / 100$ & $0 / 0 / 55 / 73$ & $84 / 84 / 84 / 84$ & $85 / 85 / 85 / 85$ \\
\hline GSPB 2315 & $128 / 128 / 128 / 128$ & 78/78/78/78 & $0 / 0 / 0 / 4$ & 79/79/79/79 & 91/91/91/91 & $0 / 14 / 14 / 101$ & $106 / 106 / 106 / 106$ & $0 / 0 / 0 / 38$ & $102 / 102 / 102 / 102$ & $82 / 82 / 82 / 82$ \\
\hline GSPB 2221 & $103 / 103 / 103 / 103$ & 79/79/79/79 & $7 / 7 / 13 / 13$ & $86 / 86 / 86 / 86$ & 99/99/99/99 & 0/0/95/97 & 98/98/98/98 & 0/0/95/97 & 91/91/91/91 & 90/90/90/90 \\
\hline GSPB 2222 & $105 / 105 / 105 / 105$ & $61 / 61 / 61 / 61$ & 0/0/0/0 & $66 / 66 / 66 / 66$ & 90/90/90/90 & $0 / 0 / 0 / 81$ & 95/95/95/95 & $0 / 0 / 0 / 22$ & $103 / 103 / 103 / 103$ & $74 / 74 / 74 / 74$ \\
\hline 399 & $102 / 102 / 102 / 102$ & $47 / 47 / 47 / 47$ & $0 / 0 / 2 / 7$ & $103 / 103 / 103 / 103$ & $75 / 75 / 75 / 75$ & $0 / 0 / 87 / 87$ & $100 / 100 / 100 / 100$ & 0/0/99/101 & 97/97/97/97 & $87 / 87 / 90 / 90$ \\
\hline GSPB 3133 & $103 / 103 / 103 / 103$ & $88 / 88 / 88 / 88$ & $0 / 0 / 0 / 0$ & $23 / 23 / 23 / 23$ & $87 / 87 / 87 / 87$ & 0/59/59/66 & 92/92/92/92 & $0 / 0 / 34 / 47$ & $85 / 85 / 85 / 85$ & $94 / 94 / 94 / 94$ \\
\hline 185 & 98/98/98/98 & $81 / 81 / 81 / 81$ & $0 / 0 / 0 / 0$ & $29 / 29 / 29 / 29$ & 98/98/98/98 & $86 / 98 / 98 / 98$ & $80 / 80 / 80 / 80$ & $0 / 114 / 115 / 115$ & $100 / 100 / 100 / 100$ & $89 / 89 / 89 / 89$ \\
\hline Leningrad 3 & $107 / 107 / 107 / 107$ & $61 / 61 / 61 / 61$ & $0 / 0 / 42 / 43$ & $81 / 81 / 81 / 81$ & $110 / 110 / 110 / 110$ & $0 / 55 / 80 / 81$ & 98/98/98/98 & $0 / 0 / 83 / 85$ & $84 / 85 / 85 / 85$ & $106 / 106 / 106 / 106$ \\
\hline All strains & $104 / 104 / 104 / 104$ & $85 / 85 / 85 / 85$ & $2 / 2 / 5 / 5$ & $74 / 74 / 74 / 74$ & 95/96/96/96 & $6 / 29 / 70 / 84$ & 95/95/95/95 & $0 / 17 / 53 / 62$ & $89 / 91 / 92 / 92$ & $88 / 88 / 89 / 89$ \\
\hline
\end{tabular}

${ }^{\mathrm{a}}$ In all, 100 to $250 \mathrm{CFU}$ were plated in triplicate onto each medium. Plating efficiency percent $=(\mathrm{CFU}$ of $\mathrm{Cmm}$ on test medium/CFU of $\mathrm{Cmm}$ on NGY $) \times 100$.

Each value for each strain and test medium was derived from triplicate.

TABLE 4. Selectivity and detection sensitivity of the media BCT and BCT-2 for Clavibacter michiganensis subsp. michiganensis (Cmm) occurring in tomato seed and plant homogenates which contained high concentrations of saprophytic bacteria, compared with eight earlier published semiselective media

\begin{tabular}{|c|c|c|c|c|c|c|c|c|c|c|c|c|c|c|}
\hline \multirow[b]{3}{*}{ Medium } & \multicolumn{14}{|c|}{ Inhibition of saprophytes (Inhib.) and visible detection (Det.) of $\mathrm{Cmm}(\%) \mathrm{in}^{\mathrm{a}}$} \\
\hline & \multicolumn{2}{|c|}{ A } & \multicolumn{2}{|c|}{$\mathrm{B}$} & \multicolumn{2}{|c|}{$\mathrm{C}$} & \multicolumn{2}{|c|}{$\mathrm{D}$} & \multicolumn{2}{|c|}{$\mathrm{E}$} & \multicolumn{2}{|c|}{$\mathrm{F}$} & \multicolumn{2}{|c|}{ Average } \\
\hline & Inhib. & Det. & Inhib. & Det. & Inhib. & Det. & Inhib. & Det. & Inhib. & Det. & Inhib. & Det. & Inhib. & Det. \\
\hline KBT & 84.9 & 0.0 & 81.0 & 0.0 & 80.9 & 0.0 & 98.6 & 0.0 & 72.5 & 0.0 & 74.8 & 0.0 & 82.1 & 0.0 \\
\hline $\mathrm{mCNS}$ & 95.1 & 0.0 & 98.6 & 0.0 & 98.4 & 0.0 & 100.0 & 0.0 & 99.2 & 0.0 & 98.3 & 0.0 & 98.3 & 0.0 \\
\hline EPPO & 95.6 & 0.0 & 98.3 & 0.0 & 97.8 & 0.0 & 100.0 & 0.0 & 94.7 & 0.0 & 97.9 & 0.0 & 97.4 & 0.0 \\
\hline CMM1 & 88.0 & 0.0 & 87.8 & 0.0 & 98.6 & 0.0 & 98.1 & 0.0 & 98.8 & 0.0 & 77.4 & 0.0 & 91.5 & 0.0 \\
\hline $\mathrm{mSCM}$ & 88.4 & 0.0 & 95.5 & 0.0 & 95.8 & 0.0 & 97.6 & 0.0 & 99.7 & 0.0 & 95.2 & 0.0 & 95.4 & 0.0 \\
\hline BCT & 97.8 & 67.3 & 98.0 & 39.7 & 98.7 & 100.0 & 99.4 & 66.7 & 98.6 & 100.0 & 98.2 & 25.0 & 98.5 & 66.4 \\
\hline ВCT-2 & 99.8 & 63.6 & 98.0 & 50.0 & 99.3 & 98.4 & 99.6 & 0.0 & 98.1 & 0.0 & 100.0 & 0.0 & 99.1 & 35.3 \\
\hline
\end{tabular}

${ }^{a} \mathrm{~A}, \mathrm{~B}, \mathrm{C}, \mathrm{D}, \mathrm{E}$, and $\mathrm{F}=$ different seed or plant homogenates plated onto selective media and containing different cell-numbers of saprophytes (S) and Cmm, A, field seed homogenate $(11,500 \mathrm{~S}+110 \mathrm{Cmm}$ BO-RS/agar plate); B, field plant homogenate $(18,000 \mathrm{~S}+58 \mathrm{Cmm} 382 / a g a r$ plate); C, homogenate from greenhouse plants infested $(15,000 \mathrm{~S}+250 \mathrm{Cmm}$ BO-RS/agar plate); D, field seed homogenate $(1,150+21 \mathrm{Cmm}$ BO-RS/agar plate); E, homogenate of field plants (1,200 S + $3 \mathrm{Cmm}$ OS-2/agar plate), and F, homogenate of field plants (12,750 S $8 \mathrm{Cmm}$ 382/agar plate). 


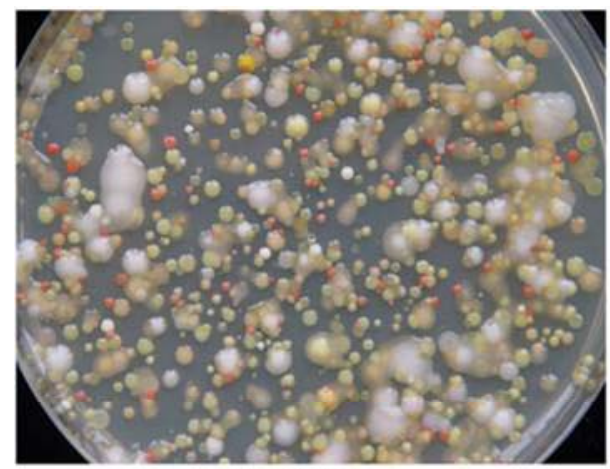

D2ANX

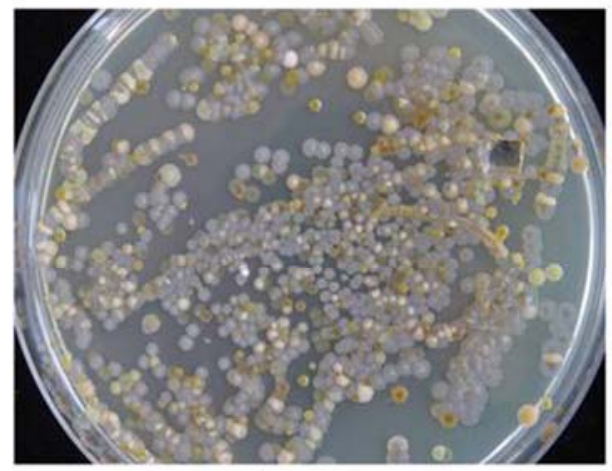

KBT

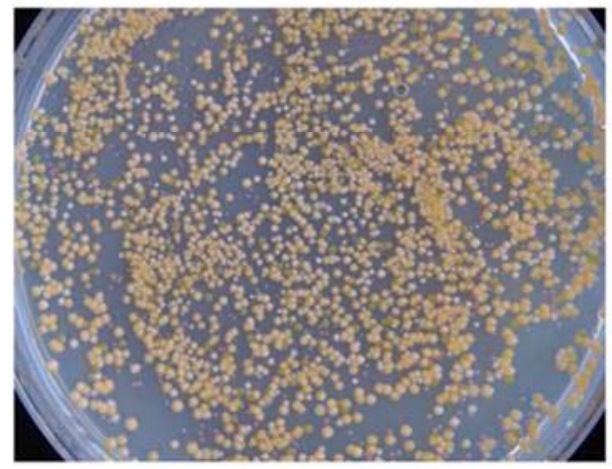

mCNS

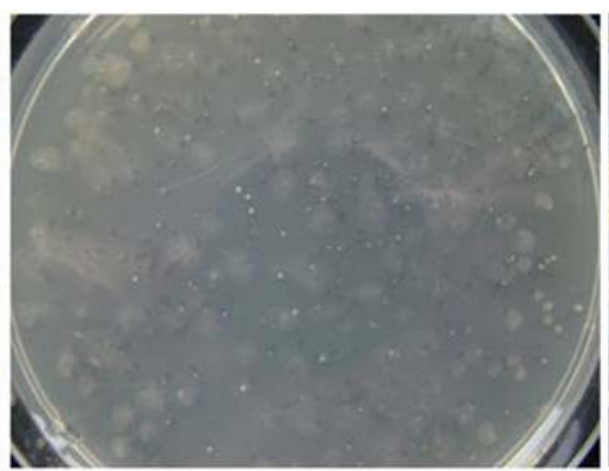

mSCM

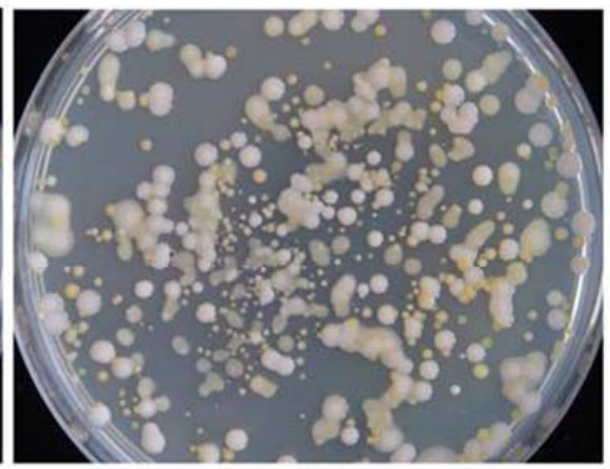

D2

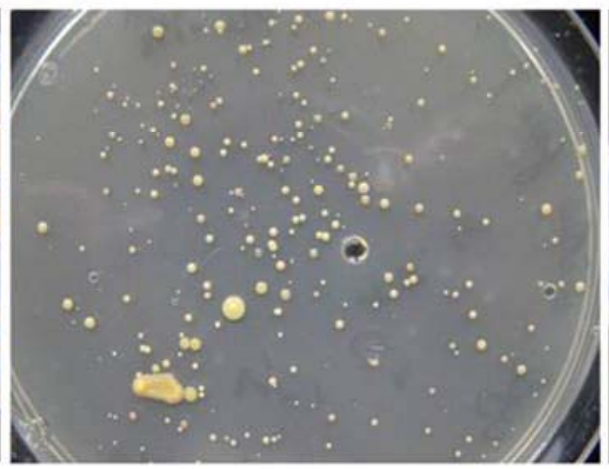

EPPO

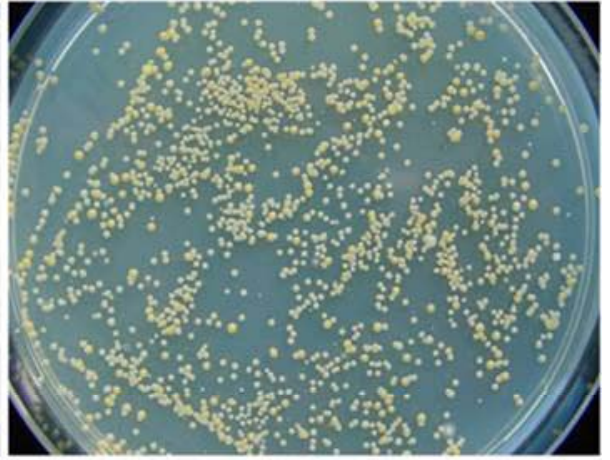

CMM1

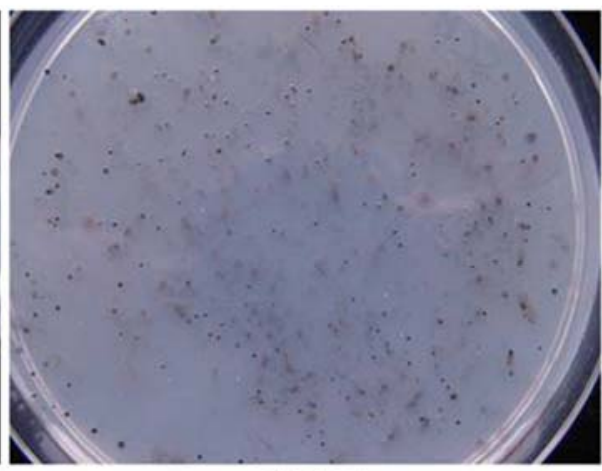

SCM

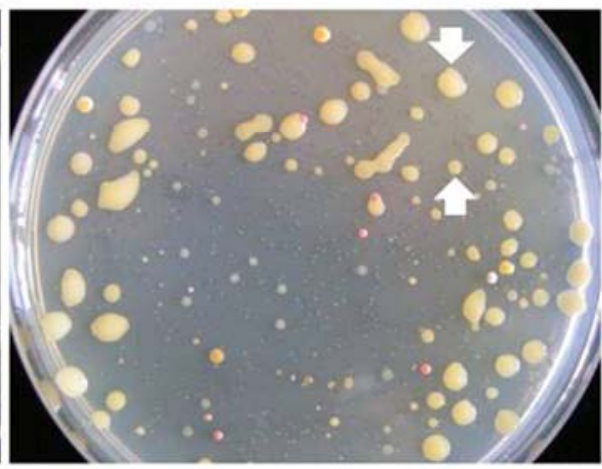

BCT

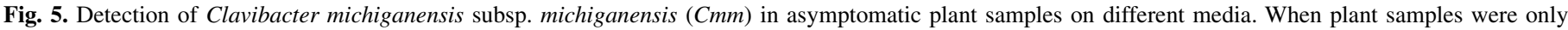

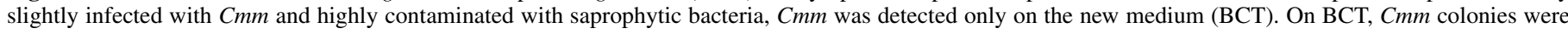

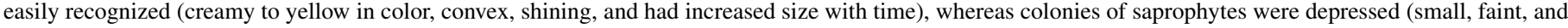
mostly white in color).

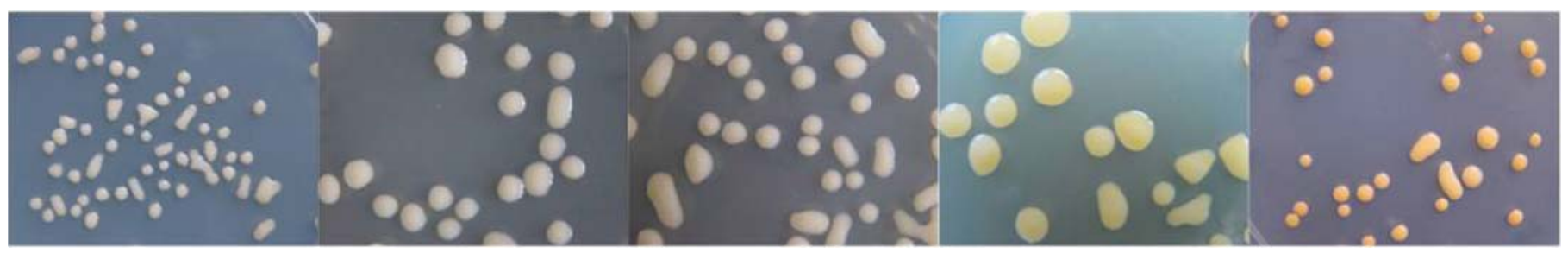

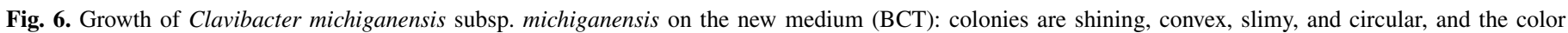
varies from white creamy at the beginning to yellow later.

Therefore, initially 40 different antibiotics, several inhibitors (boric acid, lithium chloride, potassium tellurite, and sodium azide), and 31 fungicides were tested. Finally, three antibiotics (polymyxin B sulfate, nalidixic acid, and trimethoprim), the inhibitor boric acid, and the fungicide Opus Top were selected and tested in manifold combinations (13).

Polymyxin B sulfate has a very broad inhibiting spectrum on nontarget organisms and considerably enhances the selectivity. A concentration of $20 \mathrm{mg} / \mathrm{liter}(8,120 \mathrm{IU} / \mathrm{mg})$ was actually toxic toward $\mathrm{Cmm}$ when applied in the basal medium. However, this toxic effect on $\mathrm{Cmm}$ was prevented when boric acid was also added to the medium. In contrast, the toxic effect of polymyxin B sulfate against a large variety of accompanying saprophytes tested so far was not prevented by addition of boric acid. Thus, polymyxin B sulfate at $20 \mathrm{mg} / \mathrm{liter}$ and boric acid at $600 \mathrm{mg} / \mathrm{liter}$ together supported the medium with higher selec- 


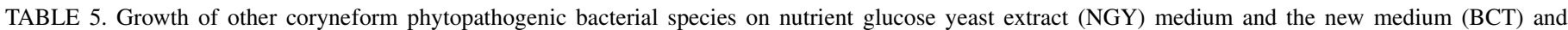
colony diameter after 7 days

\begin{tabular}{|c|c|c|c|}
\hline \multirow[b]{2}{*}{ Bacterial species } & \multicolumn{2}{|c|}{ Colony diameter $(\mathrm{mm})$ on } & \multirow{2}{*}{$\frac{\text { Plating efficiency }(\%) \text { on }}{\text { BCT }}$} \\
\hline & NGY & BCT & \\
\hline Clavibacter michiganensis subsp. insidiosus (GSPB 30) & $2.0-5.0$ & $1.0-1.8$ & 68.0 \\
\hline C. michiganensis subsp. nebraskensis (GSPB 2223) & $2.0-5.0$ & $2.0-3.0$ & 99.0 \\
\hline C. michiganensis subsp. tessellarius (GSPB 2224) & $2.0-5.0$ & $1.5-2.5$ & 98.0 \\
\hline C. michiganensis subsp. sepedonicus (GSPB 1522) & 0.5 & 0.0 & 0.0 \\
\hline C. michiganensis subsp. sepedonicus (GSPB 2823) & 0.2 & 0.0 & 0.0 \\
\hline Curtobacterium flaccumfaciens pv. flaccumfaciens (GSPB 2218) & $2.0-4.0$ & 0.0 & 0.0 \\
\hline
\end{tabular}

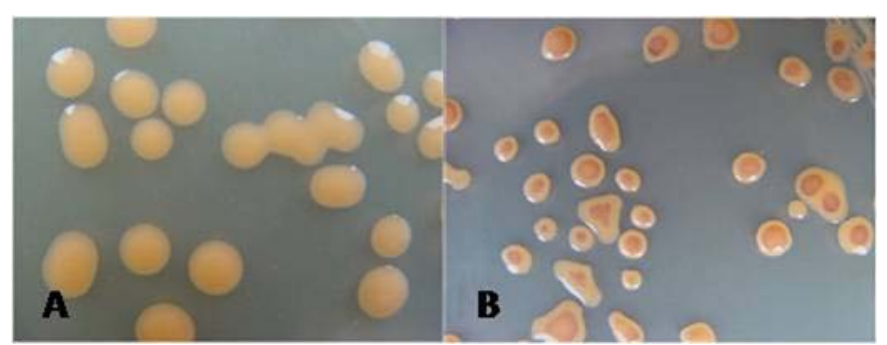

Fig. 7. A, Clavibacter michiganensis subsp. tessellarius GSPB 2224 and B, $C$. michiganensis subsp. insidiosus GSPB 30 on the new medium (BCT).

tivity and allowed a very good growth of all $\mathrm{Cmm}$ strains tested, whereas very low or no growth of $\mathrm{Cmm}$ was recorded without boric acid.

The underlying mechanism for this effect, which was never observed against any of the other bacterial species tested, is still unknown and can only be speculated upon. Because the toxicity of the other antibiotics contained in the new medium was not reduced by boric acid, it is possible that the sulfate ion bound exclusively to polymyxin B is partially replaced by borate, resulting in lowered influx of polymyxin B into the Cmm cells. It is possible that unique structures of the teichoic or teichuronic acid cell wall (29) or other cell wall components of the target bacterial species are responsible for this effect. Obviously, specific interactions between bacterial cell wall components with polymyxin B sulfate and boric acid are involved. Further investigations are needed to elucidate this phenomenon. Because only the very closely related subspecies insidiosus, nebraskensis, and tessellarius showed a similar response, it should also be investigated whether this feature plays a role in colonization of the plant xylem by these pathogens.

In contrast to nearly all previous semiselective media developed for $\mathrm{Cmm}$, which use either boric acid or polymyxin B sulfate separately, we combined these two compounds. By addition of boric acid, the plating efficiency of $\mathrm{Cmm}$ was significantly enhanced concomitantly with selectivity on an extremely high level. Although the EPPO medium uses a similar approach by containing polymyxin B sulfate and boric acid together, this medium is rather toxic to several $\mathrm{Cmm}$ strains. This may be due to the higher concentration of polymyxin B sulfate and the composition of the basal medium, which is not well suited for Cmm growth.

Similarly to the MTNA medium for $C$. michiganensis subsp. sepedonicus (20), BCT contains the antibiotic trimethoprim, as was reported by Ftayeh et al. (16). Later, Koenraadt et al. (26) confirmed that trimethoprim was well suited in semiselective media for detection of $\mathrm{Cmm}$. Trimethoprim has never been used in other semiselective media for $\mathrm{Cmm}$ before, but it supported the medium with additional efficacy against some saprophytic bacteria that were not affected by polymyxin B sulfate or by nalidixic acid.

As a result of this study, we developed the new selective medium BCT for a highly sensitive detection of $\mathrm{Cmm}$. We detected extremely low $\mathrm{Cmm}$ populations in tomato plants and seed on
BCT, even when the pathogen was present in 1,000-fold lower concentration than accompanying nontarget bacteria. Such highly sensitive detection was impossible with any of the earlier published semiselective media for $\mathrm{Cmm}$. Therefore, BCT should be very helpful in improving the detection sensitivity of the pathogen in tomato seed and transplants and, thus, allow an effective control of bacterial canker of tomato.

\section{ACKNOWLEDGMENTS}

This study was supported, in part, by the Georg-August University of Göttingen, the German Academic Exchange Service, and the HannsSeidel-Foundation. Fatty acid methyl ester analyses were kindly carried out under the supervision of D. Felgentreu, Institute for Ecological Chemistry, Plant Analysis and Stored Products Protection, Julius-KühnInstitut, Berlin. We thank H. Eiffert, Institute of Medical Microbiology, University of Göttingen, for supplying us with different antibiotics needed for the initial screening tests; and C. Nordmann for her excellent technical assistance.

\section{LITERATURE CITED}

1. Alvarez, A. M., and Kaneshiro, W. S. 1999. Detection and identification of Clavibacter michiganensis subsp. michiganensis in tomato seed. Pages 93-97 in: Proc. 3rd Int. Seed Testing Assoc. Plant Dis. Comm. Seed Health Symp. Iowa State University. J. W. Sheppard, ed. The International Seed Testing Association, Zürich.

2. Bauer, A. W., Kirby, W. M. M., Sherris, J. C., and Turck, M. 1966. Susceptibility testing by a standardized single disc method. Am. J. Clin. Pathol. 45:493-496.

3. Biggerstaff, C. M., Gleason, M. L., and Braun, E. J. 2000. Refinement of a nondestructive tomato seed assay for Clavibacter michiganensis ssp. michiganensis using seed fiber. Seed Sci. Technol. 28:261-269.

4. CABI/EPPO. 2009. Clavibacter michiganensis subsp. michiganensis. Distribution Maps of Plant Diseases. No. 26 (Edition 9). CABI, Wallingford, UK.

5. Chang, R. J., Ries, S. M., and Pataky, J. K. 1991. Dissemination of Clavibacter michiganensis subsp. michiganensis by practices used to produce tomato transplants. Phytopathology 81:1276-1281.

6. Chun, W. C. C. 1982. Identification and detection of Corynebacterium michiganense in tomato seed using the indirect enzyme-linked immunosorbent assay. M.Sc. thesis, University of Hawaii, Honolulu.

7. Council Directive 2000/29/EC of 8 May 2000 on protective measures against the introduction into the Community of organisms harmful to plants or plant products and against their spread within the Community. Off. J. Eur. Communities L 169:1-112.

8. Davis, M. J., Gillaspie, A. G., Jr., Vidaver, A. K., and Harris, R. W. 1984. Clavibacter, a new genus containing some phytopathogenic coryneform bacteria Clavibacter xyli subsp. xyli sp. nov., subsp. nov. and Clavibacter xyli subsp. cynodontis subsp. nov., pathogens that cause ratoon stunting disease of sugarcane and bermudagrass stunting disease. Int. J. Syst. Bacteriol. 34:107-117.

9. De la Cruz, A. R. 1990. Detection, weed host, and biological suppression of the potato ring rot bacterium, Clavibacter michiganensis subsp. sepedenicus. Ph.D. thesis, University of Idaho, Moscow.

10. Dhanvantari, B. N. 1987. Comparison of selective media for isolation of Clavibacter michiganense pv. michiganense. (Abstr.) Phytopathology 77:1694.

11. Fatmi, M., and Schaad, N. W. 1988. Semiselective agar medium for isolation of Clavibacter michiganensis sp. michiganensis from tomato seed. Phytopathology 78:121-126.

12. Ftayeh, R. 2004. Vorkommen, Epidemiologie und Bekämpfungsmöglichkeiten der bakteriellen Tomatenwelke (Clavibacter michiganensis ssp. 
michiganensis) auf der Insel Reichenau. Magisterarbeit, Universität Göttingen, Germany.

13. Ftayeh, R. 2010. Investigations on the elimination of Clavibacter michiganensis subsp. michiganensis, the causal agent of bacterial canker, from tomato cultures by highly sensitive detection methods and effective seed treatments. Ph.D. thesis, Georg-August-University of Göttingen, Germany.

14. Ftayeh, R., von Tiedemann, A., Koopmann, B., Abu-Ghorrah, M., and Rudolph, K. 2010. Occurrence of Clavibacter michiganensis subsp. michiganensis, the causal agent of bacterial canker of tomato, in Syria. Phytopathol. Mediterr. 49:172-178.

15. Ftayeh, R., von Tiedemann, A., Koopmann, B., Rudolph, K., and AbuGhorrah, M. 2008. First record of Clavibacter michiganensis subsp. michiganensis causing canker of tomato plants in Syria. Plant Dis. 92:649.

16. Ftayeh, R., von Tiedemann, A., und Rudolph, K. 2008. Entwicklung eines semi-selektiven Mediums für Clavibacter michiganensis ssp. michiganensis. Mitt. J. K. Inst. 417:145.

17. Gitaitis, R. D., Beaver, R. W., and Voloudakis, A. E. 1991. Detection of Clavibacter michiganensis subsp. michiganensis in symptomless tomato transplants. Plant Dis. 75:834-838.

18. Gross, D. C., and Vidaver, A. K. 1979. A selective medium for isolation of Corynebacterium nebraskense from soil and plant parts. Phytopathology 69:82-87.

19. Hadas, R., Kritzman, G., Klietman, F., Gefen, T., and Manulis, S. 2005. Comparison of extraction procedures and determination of the detection threshold for Clavibacter michiganensis ssp. michiganensis in tomato seeds. Plant Pathol. 54:643-649.

20. Jansing, H., and Rudolph, K. 1998. Physiological capabilities of Clavibacter michiganensis ssp. sepedonicus and development of a semiselective medium. J. Plant Dis. Prot. 105:590-601.

21. IPPC. 2007. Clavibacter michiganensis spp. michiganensis on tomato plants intended for planting. Pest Report NLD-09/1 of the Netherlands Plant Protection Organization (NPPO). International Plant Protection Convention (IPPC). https://www.ippc.int/index.php?id=138\&tx pestreport_pi1[showUid] $=184100 \&$ frompage $=138 \&$ type $=$ pest_report $\&$ su btype $=\& \mathrm{~L}=0$ \#item.
22. ISHI. 2008. Method for the Detection of Clavibacter michiganensis subsp. michiganensis on Tomato seed (Version 3). International Seed Health Initiative. http://www.worldseed.org/cms/medias/file/TradeIssues/ PhytosanitaryMatters/SeedHealthTesting/ISHI-Veg/Tomato_Cmm_2008.pdf

23. Kado, C. I., and Heskett, M. G. 1970. Selective media for isolation of Agrobacterium, Corynebacterium, Erwinia, Pseudomonas, and Xanthomonas. Phytopathology 60:969-976.

24. Kaneshiro, W. S. Mizumoto, C. Y, and Alvarez, A. M. 2006. Differentiation of Clavibacter michiganensis subsp. michiganensis from seed-borne saprophytes using ELISA, Biolog and 16S rDNA sequencing. Eur. J. Plant Pathol. 116:45-56.

25. King, E. O., Ward, M. K., and Raney, D. E. 1954. Two simple media for the demonstration of pyocyanin and fluorescin. J. Lab. Clin. Med. 44:301-307.

26. Koenraadt, H., van Vliet, A., Neijndorff, N., and Woudt, B. 2009. Improvement of semi-selective media for the detection of Clavibacter michiganensis subsp. michiganensis in seeds of tomato. (Abstr.) Phytopathology 99:S66.

27. OEPP/EPPO. 2005. EPPO standards PM 7/42 diaganostics. Clavibacter michiganensis subsp. michiganensis. OEPP/EPPO Bull. 35:275-283.

28. Olivier, V., Baloche, A., Drouin, A., Audusseau, C., Paillard, S., and Soubelet, H. 2009. Internal validation and collaborative study on Clavibacter michiganensis subsp. michiganensis in seeds: An example of a European cooperation. In: EPPO Conf. Diagnostics Associated Workshops, York, UK.

29. Rodgers, H. J., Perkins, H. R., and Ward, J. B. 1980. Microbial Cell Walls and Membranes. Chapman and Hall, New York

30. Strider, D. L. 1969. Bacterial canker of tomato caused by Corynebacterium michiganense, a literature review and bibliography. N. C. Agric. Exp. Stn. Tech. Bull. No. 193.

31. Waters, C. M., and Bolkan, H. A. 1992. An improved semi-selective medium and method of extraction for detecting Clavibacter michiganensis ssp. michiganensis in tomato seeds. (Abstr.) Phytopathology $82: 1072$.

32. Werner, N. A., Fulbright, D. W., Podolsky, R., Bell, J., and Hausbeck, M K. 2002. Limiting populations and spread of Clavibacter michiganensis subsp. michiganensis on seedling tomatoes in the greenhouse. Plant Dis. 86:535-542. 